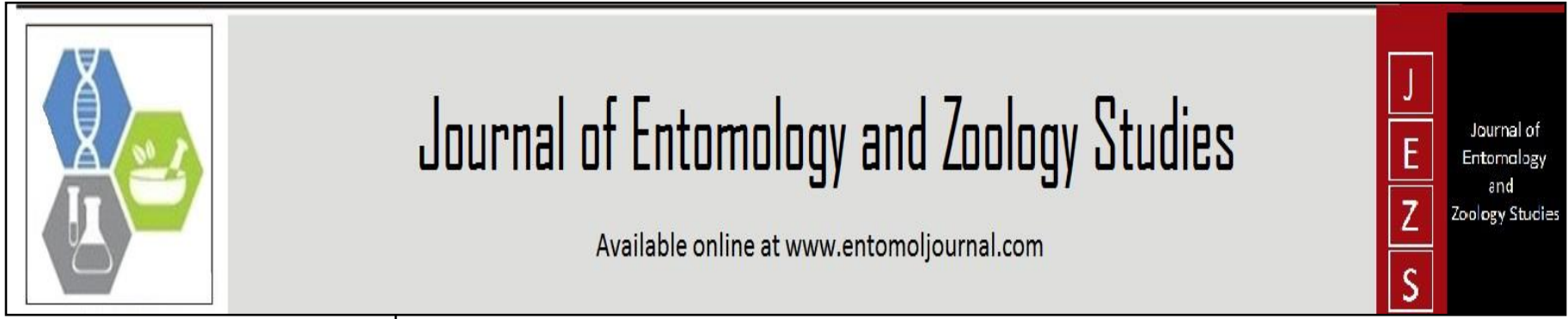

E-ISSN: 2320-7078

P-ISSN: 2349-6800

www.entomoljournal.com

JEZS 2020; 8(4): 1818-1822

(C) $2020 \mathrm{JEZS}$

Received: 21-05-2020

Accepted: 23-06-2020

\section{A Rajbongshi}

Krishi Vigyan Kendra, Assam

Agricultural University, Nalbari,

Assam, India

\section{A Ali}

Krishi Vigyan Kendra, Assam Agricultural University, Nalbari,

Assam, India

\section{Chakravarty}

Krishi Vigyan Kendra, Assam Agricultural University, Nalbari, Assam, India

\section{Deka}

Krishi Vigyan Kendra, Assam Agricultural University, Nalbari, Assam, India

\section{H Mazumdar}

Krishi Vigyan Kendra, Assam

Agricultural University, Nalbari,

Assam, India

S Baishya

College of Fisheries, Assam Agricultural Universities, Raha, Nagaon, Assam, India
Corresponding Author:

A Rajbongshi

Krishi Vigyan Kendra, Assam Agricultural University, Nalbari, Assam, India

\section{Studies on induce breeding performance of magur (Clarias batrachus) in FRP hatchery installed at Nalbari district, Assam}

\author{
A Rajbongshi, A Ali, M Chakravarty, M Deka, H Mazumdar and S \\ Baishya
}

DOI: https://doi.org/10.22271/j.ento.2020.v8.i4ac.7400

\begin{abstract}
A study was conducted to evaluate the effect of Ovaprim on induced breeding of Magur (Clarias batrachus) in FRP hatcheries H-1, H-2 and H-3 installed in three farms of Nalbari district, Assam for survival of magur larvae. The Ovaprim hormone was found to be efficient in breeding operations of the hatcheries in dose combinations as $1.35 \pm 0.15,1.95 \pm 0.15$ and $1.16 \pm 0.17$ used in $\mathrm{H}-1, \mathrm{H}-2$ and $\mathrm{H}-3$ respectively. It was obvious that the average relative fecundity, body weight and ovulation percentage in $\mathrm{H}-2$ hatchery were higher compared to $\mathrm{H}-1$ and $\mathrm{H}-3$ which is mainly due to proper feeding and nutrition. The highest \% normal larvae was observed in $\mathrm{H} 2$ hatchery which was $67.72 \pm 13.01$ which is due to the effect of different doses of Ovaprim during induced breeding of Magur. The study revealed that FRP hatcheries can be a potential tool for induced breeding and quality seed production of Magur.
\end{abstract}

Keywords: Induced breeding, Magur, FRP hatchery, Assam

\section{Introduction}

Fishes play an integral part of the cultural and traditional life of the people of North East India. Apart from carps, air breathing catfishes viz. Magur, Kawoi, Singhi and Pabda are most preferred fish species owing to their taste and nutritive value in North East India including Assam ${ }^{[1]}$. The beels and wetlands of Assam are the main habitats of these fishes. The declining trend of capture fisheries from the natural water bodies has resulted in paucity of the indigenous varieties of fishes viz. Magur, Kawoi, Singhi and Pabda in daily markets used for human consumption ${ }^{[3]}$. Sarkar and Ponniah ${ }^{[4]}$ evaluated that North East India is considered as one of the hot spots of freshwater fish biodiversity in the world. Studies revealed that out of 186 fish species, $62(33.16 \%)$ are considered as only food fish. As far as economic value is concerned, it is evaluated that out of 186 species 34 fish species have market demand better than Indian major carps whereas 19 species have similar economic values and consumer preference (Sarkar and Ponniah) ${ }^{[4]}$. This indicates that there lies great potential of freshwater fish species in the entire North East India to produce through culture of the indigenous fish species. Though the state of Assam is dominated by carp culture (more than 95\%) but some of the indigenous species fetch more price over carp [2] i.e. Magur, Anabas, Murrel, Mystus, Pabda, Anabas, Wallago, Chitala etc. It fetches nearly INR 700-1000 per kg. The present scenario depicts that the demand of catfish seed has been increasing over entire North-East. However, the quantity of the catfish seeds that are being produced in Assam is not sufficient to meet the demand of the local people because of which they have adopted the route of import from Bangladesh via Kolkata, India. Moreover, due to lack of quality seeds of catfish these innovative systems are unable to flourish in proper way. Everyday lakhs of seeds are entering in Assam from Bangladesh through Kolkata which in turn takes out a major share of revenue in crores out of the state. Through the incorporation of scientific ventures, the production of quality seeds of Kawai (Anabus testudineus), Singhi (Heteropneustes fossilis), Magur (Clarias batrachus), Pabho (Ompak spp.) etc. has been achieved and which can be supplied to Northeastern states of the country. However, the induce breeding of catfish is still difficult in terms of operational procedures and farmers are not at great ease in terms of producing seeds. Some of the difficulties that are usually encountered during breeding and seed rearing processes 
include clean and potable water, daily removal of metabolites and unavailability of live feeds particularly for larvae and fry of catfishes, appropriate design of nursery ponds for catfishes. These difficulties can be regarded as the reasons for halting the way of achieving optimum production of quality seeds of catfishes. Though ICAR-CIFA, Bhubaneswar, India one of the leading institutions in freshwater fisheries research and development has claimed successful breeding of these species but the technology is yet to be realized by the farming community in terms of technology replication. The demand for seeds of catfish has been increasing day by day for last two years and the growing demand could be met through FRP hatcheries developed by ICAR-CIFA. Hence, the importance of artificially propagated seeds is felt necessary for propagation and culture of these important species. Scientists of $\mathrm{KVK}$ as well as a bunch of enthusiastic farmers are trying to address the induce breeding operation and some of them are able to succeed. Seeing the keen interest of these farmers in seed production of Magur, Krishi Vigyan Kendra (KVK), Assam Agricultural University, Nalbari, Assam collaborated with ICAR-CIFA, Bhubaneswar, India for procurement of portable FRP magur hatcheries for those farmers. As a result, a total of five FRP magur hatcheries were received from CIFA. A group of young and enthusiastic fish farmers of the Nalbari district under the leadership of KVK, Nalbari are now engaged in induce breeding and seed rearing of local magur (Clarias batrachus) and climbing perch (Anabas testudineus) through hands on training and demonstration. The successful venture of these farmers has attracted other fish farmers of the district and they were trained for magur and kawoi breeding under the guidance of KVK, Nalbari. The Nalbari district is now an epicenter for magur and kawoi seed hub for the farmers of different districts of Assam viz. Bongaigaon, Jorhat, Sivsagar, Lakhimpur, Kamrup, Darrang, Sonitpur etc. The present study was carried out with a view to find out the performance of induce bred magur in FRP hatcheries at farmers' field and its impact on survival at different stages of development particularly eggs and spawn.

\section{Materials and methods}

The study was conducted in Nalbari district, located in Central Western part of Assam State between $91^{\circ} 07^{\prime} \mathrm{E} 91^{0}$ $47^{\prime} \mathrm{E}$ latitudes and $26^{\circ} \mathrm{N}$ and $58^{\circ} 5^{\prime} \mathrm{N}$ longitude. The total geographical area of the district is $1052 \mathrm{sq} \mathrm{km}$, which is $2.6 \%$ of the total area of the state of Assam. The three different hatcheries selected for study was located in Nalbari district were designated as $\mathrm{H}-1, \mathrm{H}-2$ and $\mathrm{H}-3$.

\section{Portable FRP Magur hatchery for seed production developed by ICAR-CIFA}

Witnessing the keen interest some farmers of Nalbari district for seed production of Magur, the KVK, AAU, Nalbari, Assam collaborated with ICAR-CIFA, Bhubaneswar for procurement of portable FRP magur hatcheries for those farmers and was established in three different locations of Nalbari district, Assam. The portable magur hatchery was a fabrication fiberglass reinforced plastic (FRP) and consisted of a circular tank of $2 \mathrm{~m}$ diameter with 5-6 inlets at the intersection of the tank wall and bottom surface. These inlets supply turbulent water flow fitted at an angle of $45^{\circ}$. It had a capacity of holding 30,000 fertilized eggs in a single cycle. This turbulent water flow was provided to maintain flowing water (lotic habitat) and dissolved oxygen for fertilized eggs. The main advantages of FRP hatcheries were light weight, easy to transport and it could be assembled and dismantled easily.

\section{Working practices of the selected FRP hatcheries}

Study of breeding and larval rearing of indigenous magur was carried out during the year 2018-2019 and 2019-2020 in three different fish farms of Nalbari district. The farmers started breeding of Magur during the breeding season from AprilJune of every year i.e. during the onset of monsoon. Farmers were able to complete 15-20 cycles of breeding operations for magur during a single breeding period. The working schedule maintained during the study is as follows:

\section{Seed production technique of Magur (Clarias batrachus)}

The farmers collected brooders of Magur raised in captive conditions in earthen ponds in Nalbari district, Assam. Brooders were fed twice daily with fish meal based feed containing 30-35\% protein @ 3-5\% of the body weight. The brood stock of magur having average weight of $150 \mathrm{gm}$ each were used for breeding in FRP hatcheries. Farmers maintained ideal sex ratio 1:2 (male and female) for higher rate of fertilization although sometimes it depends on the release of egg. Farmers selected female magur by their soft, swollen abdomen and males were selected by their flat abdomen and long protruded button shaped round genital papillae. For induced breeding, the farmers purchased synthetic hormones such as Ovaprim/Ovatide/WOVA-FH which were commercially available in the market and injected into the females@1.0-1.5 ml/kg body weight for induce ovulation. Injection was administered intramuscularly on the fleshy part of the dorsal side of females. However, males did not require any hormonal induction of spawning. The sperm suspension was prepared by mascerating testis in normal saline solution $(0.9 \%$ Sodium chloride, $\mathrm{NaCl}: 9 \mathrm{~g}$ in 1 litre of water). The stripping of female was done after a latency period of 16-17 hours to get the best-quality eggs. After collection of eggs through stripping it was placed in plastic trays and fertilized with the prepared sperm suspension. With the help of feather, the eggs were mixed and little quantity of water was added for activation of sperm which would help for successful fertilization of eggs. After 2-3 minutes of mixing, the eggs were washed thoroughly in running water and shifted to incubation tray. The incubation tray size was 1 foot (length) $\times 0.5$ foot (width). During incubation period, unfertilized eggs were removed through siphoning so as to remove the attack of fungus on eggs. The incubated eggs were hatched within 24-27 hours when the temperature was about $27-30^{\circ} \mathrm{C}$. Hatched larvae were transferred to circular fiberglass plastic (FRP) containers for rearing up to 40 days to the size of spawn about 1.5 to 2 inches in length. Aerators were installed in the larval rearing tanks for maintaining the optimum dissolved oxygen. Farmers fed larvae from the third day with live feed which was collected from pond with help of plankton net. The plankton contains mixed zooplankton which served as good larval feed during its early life stages.

\section{Quantitative Assessment of Eggs and Spawns}

In the hatchery, measurement of egg and spawn was done by volumetric method. The total volume and number of eggs laid were calculated from the known volume and number of eggs of the sample beaker $(100 \mathrm{ml})$. For more accurate results, three samples of eggs were taken and counted separately. The mean number of eggs of the three samples gave the average number of eggs per beaker. The approximate total number of eggs laid was worked out by multiplying the average number of eggs in each beaker with the number of beaker. It was represented by the following formula suggested by Chondar, Thomas, Rath ${ }^{[5,6,7]}$. 
Total number of eggs laid (approx) = Average no. of eggs in each sample beaker X No. of beakers of eggs

Total number of eggs

Relative Fecundity $=\frac{\text { Body weight }}{\text { Percentage of ovulation }(\%)=\frac{\text { Number fish ovulated }}{\text { Total number of fish }} \text { injected }} \times 100$

While counting the number of eggs in each sample, the numbers of developing good, bad and unfertilized eggs were also counted to determine the percentage of fertilization, and this was calculated by the following formula:

Percentage of fertilization $(\%)=\frac{\begin{array}{c}\text { Number of fertilized } \\ \text { eggs }\end{array}}{\begin{array}{c}\text { Total number of } \\ \text { eggs in a sample } \\ \text { (fertilized }+ \text { unfertilized) }\end{array}} \times 100$

Three samples of spawn were taken for counting the number of live and dead spawn separately in each sample beaker. The total number of spawns obtained was worked out approximately by multiplying the average number of spawn in each sample beaker with the number of beaker of spawn. Total no. of spawn produced (approx) $=$ No. of spawn in each sample beaker $\mathrm{X}$ No. of beaker of spawn. Calculation of hatching rate was calculated by following formula:

otal number of spawn

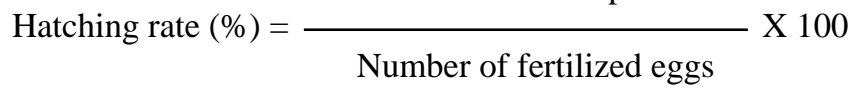

Number of hatching alive up to larvae stage

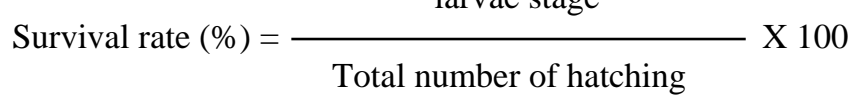

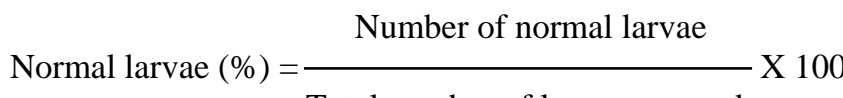

Total number of larvae counted

Abnormal larvae $(\%)=\frac{\text { Number of abnormal larvae }}{\text { Total number of larvae counted }} \times 100$

\section{Collection of general information}

Information about the hatchery owners and their household, description of culture and percentage of mortality at different stages from egg to spawn were collected and recorded. The data on hatchery operations, diseases, cost of production, problems encountered during production and assistance received from government in cash or kind were also gathered. Information was collected through personal interview of the hatchery operators and other persons involved in the hatchery operation from time to time.

\section{Statistical analysis and economic analysis}

Statistical analyses were done by analysis of variance (ANOVA) to determine significant differences among means at $\alpha=0.05$ level using statistical tools of Microsoft Office Excel (2007).

\section{Results and Discussion}

After 15 cycles of breeding operation by each hatchery operator in a year average mean \pm standard deviation was calculated. The mean data obtained from hatchery were pooled for each parameter and compared by one way analysis of variance (ANOVA) test to determine the level of significance $(p=0.05)$. ANOVA showed that the calculated $F$ value is more than the tabulated (Crit). Hence, $\mathrm{H}_{0}$ (Null hypothesis) is rejected which meant that there was significant difference $(P<0.05)$ among the three hatcheries $(\mathrm{H}-1, \mathrm{H}-2$ \& $\mathrm{H}-3)$. During this experimental study, it was observed that efficiency of Ovaprim hormone was successful in the breeding operations of the hatcheries in various combinations of doses such as $1.35 \pm 0.15,1.95 \pm 0.15$ and $1.16 \pm 0.17$ for treatment in $\mathrm{H}-1, \mathrm{H}-2$ \& $\mathrm{H}-3$ respectively. The highest dose was used in $\mathrm{H}-2$ hatchery. The average lowest latency period of $24.01 \pm 0.66$ was observed in $\mathrm{H}-2$ hatchery while $27.3 \pm 5.65$ and $31.31 \pm 6.7^{\mathrm{b}}$ were observed in $\mathrm{H}-1$ and $\mathrm{H}-3$ hatcheries respectively. Zonneveld et al. ${ }^{[8]}$ reported that right combination of the dose of inducing agent and the latency period plays the crucial role in the production of optimum quantity of eggs in catfish. Improper combination in either of these two may lead to failure in breeding operations. The present study revealed average ovulation percentage and relative fecundity recorded from the hatchery sites, H-1, H-2 $\& \mathrm{H}-3$, were $85.78 \pm 4.5,97.10 \pm 2.84,79.70 \pm 3.35$ and $9.18 \pm 2.88,10.30 \pm 1.04,7.80 \pm 5.03$ respectively (table- 1 ). The average body weight of female fishes was $170.9 \pm 18.90$, $185.5 \pm 15.2$ and $148.5 \pm 53.85$ respectively. The relative fecundity of the fishes of body weight measuring $148.5 \pm 53.85$ to $185.5 \pm 15.2$ in 3 hatcheries was $7.80 \pm 5.03$ to $10.30 \pm 1.04$ which is due to the dosages of Ovaprim hormone that determines the latency period after inducement. According to Buragohain et al. ${ }^{[9]}$ there is a relationship between fecundity with body weight (BW). The present study revealed that the average relative fecundity, body weight of fish and ovulation percentage of $\mathrm{H}-2$ hatchery were higher compared to $\mathrm{H}-1$ and $\mathrm{H}-3$ which was similar to the findings of Borgaohain et al. ${ }^{[9]}$ It appears that fecundity was more dependent on body weight. Similar relationships have also been reported earlier by Varghese ${ }^{[10]}$ who stated that the relative fecundity has curvilinear relationship of fecundity with fish body weight.

Table 1: Different parameters observed during breeding programme

\begin{tabular}{|c|c|c|c|c|c|c|}
\hline \multirow{2}{*}{ Name of hatchery } & \multirow{2}{*}{$\begin{array}{c}\text { Dose of Ovaprim } \\
\text { (ml/kg body weight) }\end{array}$} & \multirow{2}{*}{$\begin{array}{c}\text { Latency period } \\
\text { (hours) }\end{array}$} & \multicolumn{2}{|c|}{ Average body weight $(\mathbf{g m})$} & \multirow{2}{*}{ Ovulation \% } & \multirow{2}{*}{ Relative Fecundity } \\
\cline { 4 - 6 } & $1.35 \pm 0.15^{\mathrm{a}}$ & $27.3 \pm 5.65^{\mathrm{b}}$ & $161.6 \pm 32.50^{\mathrm{c}}$ & $170.9 \pm 18.90^{\mathrm{d}}$ & $85.78 \pm 4.5^{\mathrm{e}}$ & $9.18 \pm 2.88^{\mathrm{f}}$ \\
\hline H-1 & $1.95 \pm 0.15^{\mathrm{a}}$ & $24.01 \pm 0.66^{\mathrm{b}}$ & $170.9 \pm 28.92^{\mathrm{c}}$ & $185.5 \pm 15.2^{\mathrm{d}}$ & $97.10 \pm 2.84^{\mathrm{e}}$ & $10.30 \pm 1.04^{\mathrm{f}}$ \\
\hline H-2 & $1.16 \pm 0.17^{\mathrm{a}}$ & $31.31 \pm 6.7^{\mathrm{b}}$ & $136.8 \pm 39.60^{\mathrm{c}}$ & $148.5 \pm 53.85^{\mathrm{d}}$ & $79.70 \pm 3.35^{\mathrm{e}}$ & $7.80 \pm 5.03^{\mathrm{f}}$ \\
\hline
\end{tabular}

**Each observation is mean \pm standard deviation and the value marked with different letters denotes the significant difference among the hatcheries 
At the experimental site the highest fertilization (\%), hatching $(\%)$ and survival rate $(\%)$ were $88.74 \pm 4.30,76.74 \pm 12.72$, $72.85 \pm 11.91$ respectively (Table-2) in the $\mathrm{H}-2$ hatchery. This might be due to higher doses of Ovaprim $(2.0 \mathrm{ml} / \mathrm{kg})$. According to Dhara et al. ${ }^{[11]}$ the rate of fertilization and hatching of eggs were significantly higher at the higher doses of Ovaprim $(2.0 \mathrm{ml} / \mathrm{kg})$ at all the temperatures and with lower doses of Ovaprim, the rate of fertilization and hatching were significantly reduced. Time required for hatching after fertilization depends on doses of the stimulants used. Therefore, the lowest rate of fertilization $\%$, hatching $\%$ and survival rate $\%$ were $79.78 \pm 14.98,61.45 \pm 17.60,58.07 \pm 6.87^{\mathrm{b}}$ and $69.92 \pm 15.67,51.33 \pm 15.64,45.37 \pm 22.23$ observed in $\mathrm{H}-1$ and $\mathrm{H}-3$ respectively (Table-2).

Table 2: Quantitative Assessment of Eggs and Spawns

\begin{tabular}{|c|c|c|c|}
\hline Parameters & H-1 & H-2 & H-3 \\
\hline Fertilization\% & $79.78 \pm 14.98^{\mathrm{a}}$ & $88.74 \pm 4.30^{\mathrm{b}}$ & $69.92 \pm 15.67^{\mathrm{c}}$ \\
\hline Hatching \% & $61.45 \pm 17.60^{\mathrm{b}}$ & $76.74 \pm 12.72^{\mathrm{c}}$ & $51.33 \pm 15.64^{\mathrm{d}}$ \\
\hline Survival rate\% & $58.07 \pm 6.87^{\mathrm{e}}$ & $72.85 \pm 11.91^{\mathrm{f}}$ & $45.37 \pm 22.23^{\mathrm{g}}$ \\
\hline Normal larvae\% & $43.59 \pm 10.80^{\mathrm{h}}$ & $67.72 \pm 13.01^{\mathrm{i}}$ & $34.36 \pm 18.80^{\mathrm{j}}$ \\
\hline Abnormal larvae\% & $29.86 \pm 18.20^{\mathrm{k}}$ & $8.46 \pm 7.48^{1}$ & $35.28 \pm 25.87^{\mathrm{m}}$ \\
\hline
\end{tabular}
**Mean values with different superscripts were significantly
different $(p<0.05)$ evaluated using one-way ANOVA

The range of highest and lowest percentage of normal and abnormal larvae were $67.72 \pm 13.01$ to 34.36 and $8.46 \pm 7.48$ to 35.28. The study revealed that this is due to the range higher dose of Ovaprim $(1.95 \pm 0.15$ to $1.16 \pm 0.17)$ induced to the fishes. The higher percentage of deformed larvae was observed with lower dose of Ovaprim during spawning induction. According to Sahoo et al. ${ }^{[12]}$ all the mean percentage of deformed larvae was considered as the rate of deformed larvae under a particular latency period and hormone dose combination. However, the deformities in larvae at lower or higher dose may be attributed to the fertilization of unripe or over ripe ova ${ }^{[13]}$. According to Piper et al. ${ }^{[14]}$, there were possibilities of egg plugging higher stripping pressure resulted to blood tinged eggs. The blood on the stripped egg and protein from ruptured eggs coagulate and clog the micropile, which leads to poor fertilization.

The deformity of larvae was highest in the H-3 hatchery which might be due to fertilization of poor egg, adverse impact of some factors during breeding period like inbreeding, insufficiency of nutrients, disease, oxygen reduction, water current, sudden changes in temperature etc. which was similar to the deformities reported by Sahoo et al. $[15,16]$ and Sanjeevan ${ }^{[17]}$. They reported that deformities of larvae is due to the impact of several unfavorable biotic and abiotic factors during hatchery operation. According to AlHassan ${ }^{[18]}$, the low dissolved oxygen level in the water during spawning and developing stages may be responsible for deformities in fishes. During present investigation similar condition was observed in H-3 hatchery where fertilization and hatching percentage found to be lower compared to the other two hatcheries. The highest survival rate was observed in $\mathrm{H}-2$ hatchery which might be due to application of alternative live feed mainly zooplankton, boiled egg and commercial feed ( $42 \%$ protein) three times in a day and it was continued up to $40-45^{\text {th }}$ day of rearing in FRP hatchery. Sixth das onwards commercial feed containing $42 \%$ protein was given for better growth and survival of the larvae. During rearing period, commercial feed and live feed were given in the morning and afternoon respectively in $\mathrm{H}-2$ hatchery. This result corresponded with the findings of earlier workers ${ }^{[19]}$. In H-2 hatchery, operators made an easy to operate special device for removal of uneaten feed and waste particles from FRP hatcheries. They operated this device 4 times in a day. However, the H-1 and H-3 hatchery operators gave mainly live feed zooplankton two times daily and they did not maintain siphoning properly for removal of waste. According to Das ${ }^{[20]}$ the proper aeration facilities and removal of eggshells as well as debris would likely improve survival by preventing the deterioration of water quality. Das ${ }^{[20]}$ also advised the farmers to feed the young ones with boiled egg yolk and adequate densities of live food for better survival of larvae. During the study in these hatcheries there was largescale mortality during the early stages. The mortality might be due to lack of proper care during production of eggs to spawn. Fish eggs and spawn are very sensitive to the environment and mortality increases considerably if rearing conditions are not optimum.

Therefore, the present study would provide some valuable information in the improvement of induced breeding technology of $C$. batrachus which will be very important for commercial hatcheries in respect of good quality seed production. Further, the hatchery operators would be able to acquire knowledge on the different developmental stages of C. batrachus and how to take the proper management practices during rearing of their most sensitive larval stages.

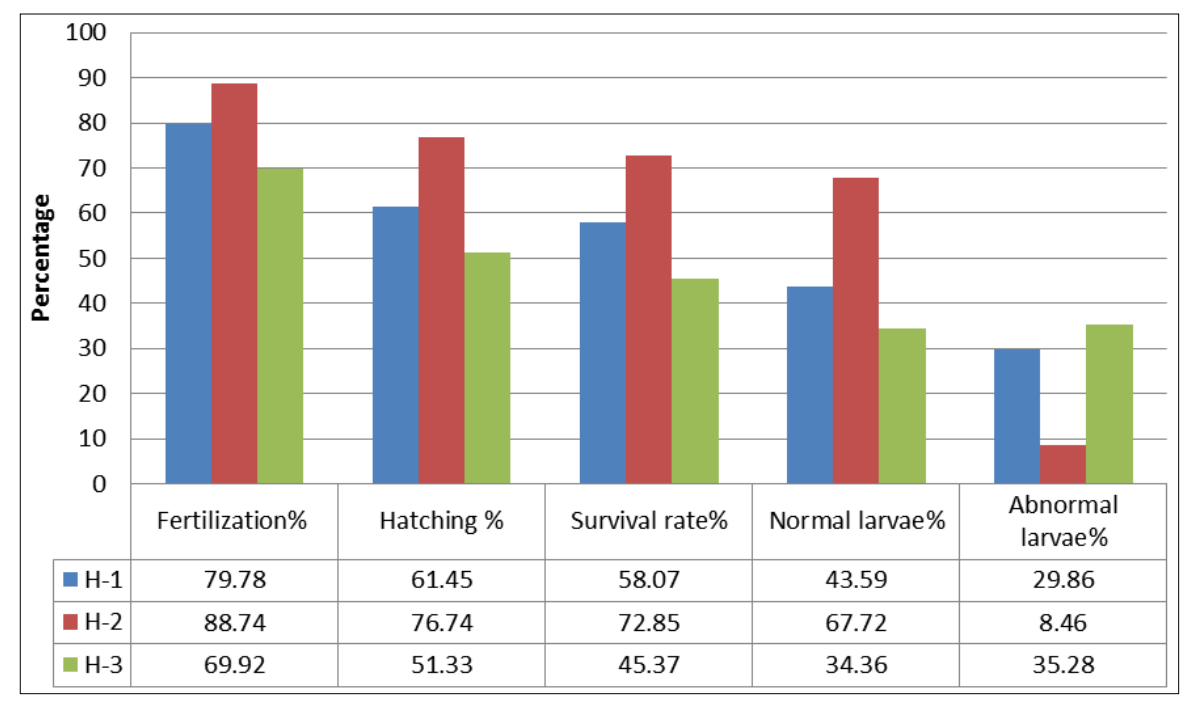

Fig 1: Comparison of different parameters 


\section{Conclusion}

Availability of successful and farmer friendly technology for induce breeding of fishes is the most important prerequisite for commercial culture and production of high value fishes. the demand of species for emergence practice of diversification of fish species in aquaculture and higher prices are attracting the progressive fish farmers towards culture of alternative fish species. Keeping the pace, progressive breeders of the North East, India are successfully breeding and producing ample seeds of about 11-12 different indigenous carp species.

However, the success of induce breeding of air breathing catfishes which have high market demand and consumer preference will be pivotal through development of farmer friendly technology for mass scale production of seeds and culture of the same. Keeping in view the local traditions and food habits of Assam as well as highly nutritive value of indigenous fishes, this technology has an immediate attraction and application in the farmers fields of the other districts of the State. The farm families of different district of Assam have been directly benefiting from this technology through training \& demonstration under the guidance of Krishi Vigyan Kendra, Nalbari. Thus, there is very fast replication of this induced breeding technology in all the district of Assam. The seed produced in the farms of the hatchery owners is made available to all farmers of the districts of Assam \& other state of North Eastern Region.

\section{References}

1. Chetia BB, Gogoi R. An observation on the amazing self healing capacity of cat fish Magur (Clarias batrachus). International Journal of Fisheries and Aquatic Studies. 2015; 2(4):38-40.

2. Barthakur S. Magur breeding and hatchery management. Proceedings of the First State Level Workshop on Current Status and Future of the Fish Seed Production Industry in the State of Assam, College of Fisheries, Assam Agricultural University, Raha, Nagaon, Assam, 1999, 17.

3. Mahapatra BK, Sardar P, Datta S. Management norms for enhancing larval survivality of magur, Clarias batrachus (Linn.). Book of Abstract Golden Jubilee National Seminar on Diversification of Aquaculture through Locally Available fish species. Organized by CIFE, Kolkata, Kolkata, India, 2010, 37.

4. Sarkar UK, Ponniah AG. Evaluation of north east Indian fish for their potential as cultivable, sport and ornamental fish as along with their conservation and endemic status. 17-30. In: AG Ponniah, UK Sarkar (eds.). Fish Biodiversity of North East India. NBFGR. NATP Publ.2, 2000, 228.

5. Chondra SL. Induced carp breeding. CBS publishers and distributors, New Delhi, 64 and, 1994, 82.

6. Thomas PC, Rath SC, Das MK. Breeding and seed production of fin fish and shell fish. Daya publisher, New Delhi, 2003, 63.

7. Rath KR. Fresh water aquaculture. Scientific publishers, Jodhpur, India, 1993, 206.

8. Zonneveld N, Rustidja WJ, Viveen AR, Maduna W. Induced spawning and egg incubation of Asian Catfish, Clarias batrachus. Aquaculture. 1988; 74(1-2):41.

9. Buragohain A, Goswami MM. Relationship of Fecundity and different body parameters of Clarias magur (Hamilton, 1822) in captive condition in the Agro climatic condition of Assam, India. IOSR Journal of Agriculture and Veterinary Science. 2014; 7(3):44-50.

10. Varghese TJ. Fecundity of Coilia dussumieri valenciennes. Proceeding of Indian National Science Academy. 1980; 46(1):114-119.

11. Dhara K, Saha NC. Controlled breeding of Asian catfish Clarias batrachus using pituitary gland extracts and Ovaprim at different temperatures, latency periods and their early development. Journal of Aquaculture Research and Development. 2013; 4(4):2-9.

12. Sahoo SK, Giri SS, Chandra S, Sahu AK. Effect of Ovaprim doses and latency periods on induced spawning of Clarias batrachus: Observation on larval deformity. Indian Journal of Experimental Biology. 2007; 45(10):920-922.

13. Sahoo SK, Giri SS, Sahu AK. Induced spawning of Asian catfish, Clarias batrachus (Linn.): effect of various latency periods and SGnRHa and domperidone doses on spawning performance and egg quality. Aquaculture Research. 2005; 36(13):1273-1278.

14. Piper RG, Ma Elwain IB, Orme LE, Mc Craren TP, Eowler LG, Leonard JR. Fish hatchery management. U. S. Dept. of Interior, Fish and Wildlife Service, Washington, D.C. 1982; 12:517.

15. Sahoo SK, Giri SS, Chandra S, Sahu AK. Observation on larval deformity during induced spawning of walking catfish, Clarias batrachus (Actinopterigii: Siluriformes: Clariidae) at different combinations of Human Chorionic Gonadotropin dose and latency period. Acta Ichthyologica Et Piscatoria. 2009; 39(1):43-45.

16. Sahoo SK, Giri SS, Swain T, Sahu AK. Observation on some common abnormalities in induced bred Clarias batrachus hatchlings. Journal Inland Fisheries Society of India. 2004; 36 (1):67-71.

17. Sanjeevan S, Anna-Mercy TV. Morphological and osteological malformations in hatchery bred redline torpedo fish, Sahyadria denisonii (Day 1865) (Cyprinidae). Anales de Biologica. 2016: 38:73-80.

18. Al-Hassan LAJ. Vertebral deformities in fishes from Iraq and the United Arab Emiretes Arabian Gulf. Iraqi Journal of Marine Science. 1982; 1(1):13-23.

19. Alam MS, Mollah MFA. Formulation of an artificial dry feed for primary nursing of catfish (Clarias batrachus L.) larvae. Bangladesh Journal of Fisheries. 1988: 11(1):7175.

20. Das SK. Seed production of Magur (Clarias batrachus) using a rural model portable hatchery in Assam, India-a farmer proven technology. Aquaculture Asia. 2002; 7(2):19-21. 